\title{
Management of Volunteer Corn Seedlings in Dry-Seeded Rice
}

\section{Bhagirath S. Chauhan*, Jhoana L. Opeña}

Weed Science, Crop and Environmental Sciences Division, International Rice Research Institute, Los Baños, Philippines. Email: ${ }^{*}$ b.chauhan@irri.org

Received September $18^{\text {th }}, 2013$; revised October $22^{\text {nd }}, 2013$; accepted November $7^{\text {th }}, 2013$

Copyright (C 2013 Bhagirath S. Chauhan, Jhoana L. Opeña. This is an open access article distributed under the Creative Commons Attribution License, which permits unrestricted use, distribution, and reproduction in any medium, provided the original work is properly cited.

\begin{abstract}
The demand for corn is increasing in Asia for feed and biofuel. It is grown in the rice-corn cropping system. During harvest of corn, however, seeds drop on the soil surface and become problems as volunteer corn seedlings in the subsequent dry-seeded rice crop, in which the suppressive effect of standing water is absent. A study was conducted in screenhouse and field conditions to evaluate the effect of rice herbicides on the management of volunteer corn seedlings. In the screenhouse experiment, bispyribac-sodium at 0.030 and $0.045 \mathrm{~kg} \cdot \mathrm{ai} \cdot \mathrm{ha}^{-1}$ provided complete control of corn seedlings. Fenoxaprop + ethoxysulfuron and penoxsulam + cyhalofop did not provide effective control of corn seedlings. In the field, the sole application of bispyribac and sequential application of oxadiazon and bispyribac suppressed corn biomass by $60 \%-82 \%$ and $89 \%$ - $91 \%$, respectively, as compared with the nontreated control. The results of this study demonstrate that, in the absence of other management strategies, volunteer corn seedlings in dry-seeded rice systems can be managed by using bispyribac-sodium.
\end{abstract}

Keywords: Volunteer Corn; Asia; Bispyribac; Seeded Rice

\section{Introduction}

Double- and triple-crop rice monoculture systems are common in tropical humid and subtropical Asia. These intensive rice production systems provide staple food for hundreds of millions of people, and they greatly affect the livelihoods of the urban and rural poor people in Asia. Recently, however, increasing demand for corn in many Asian countries has resulted in the diversification of rice monoculture systems to rice-corn cropping systems. Corn is also more water efficient than rice, especially in the wake of increasing water scarcity [1]. The rice-corn cropping system is gaining importance mainly because of increasing demand of corn for feed and biofuel [2]. Corn is grown on around 2.6 Mha in the Philippines, where it is cultivated in dry seasons.

Growing corn in the dry season and rice in the wet season can provide high total productivity in the rice-corn cropping system. In the Philippines, glyphosate-resistant corn cultivars are grown [3]. In these corn cultivars, glyphosate (a nonselective herbicide) is applied as post-

${ }^{*}$ Corresponding author. emergence, which provides very effective weed control. During harvest, a huge amount of corn seeds drop in the field, especially where corn is harvested using machines. These corn seeds germinate and emerge in the subsequent rice crop. These volunteer corn seedlings severely compete with rice crop.

In traditional puddled-transplanted rice systems, it is easy to manage volunteer corn seedlings with the use of intensive tillage in wet conditions and flooding. Because of labor and water scarcity, traditional rice systems are being replaced by mechanical-sown dry-seeded rice systems $[4,5]$. In these systems, the suppressive effect of standing water is absent. In addition, the conditions are suitable for corn germination in dry-seeded systems.

Because of intensification and diversification, there is no sufficient time to manage volunteer corn seedlings before crop planting. In such situations, there is a need to find suitable control measures for volunteer corn in dryseeded rice systems. A computer search revealed no information on the control of corn in rice. Some herbicides may be phytotoxic to corn but not to rice. However, such information is not available in the literature, especially in 
the rice-corn cropping system. Therefore, a study was conducted in controlled and field conditions to evaluate the effect of rice herbicides on volunteer corn seedlings.

\section{Materials and Methods}

Two experiments were conducted to evaluate the efficacy of different herbicides on volunteer corn seedlings. The first experiment was conducted in pots in a screenhouse and the second experiment was conducted in a field at the International Rice Research Institute, Los Baños, Philippines.

\subsection{Screenhouse Experiment}

Six plants of rice (cv. Rc222) and corn (cv P3482YR) were grown in plastic pots $(30 \mathrm{~cm}$ diameter and $27 \mathrm{~cm}$ height). Rice and corn plants were grown alternatively in the same pot. The pots were filled with $9 \mathrm{~kg}$ soil. The soil was collected from upland rice fields and it had clay, sand, and silt contents of $40 \%, 22 \%$, and $38 \%$, respectively. Rice and corn were planted on August 28, 2012. There were seven treatments; nontreated control, bispyribac-sodium (bispyribac, hereafter) applied at 0.030 and $0.045 \mathrm{~kg} \cdot \mathrm{ai} \cdot \mathrm{ha}^{-1}$ at 10 days after planting (DAP), fenoxaprop-ethyl + ethoxysulfuron applied at 0.045 and 0.068 $\mathrm{kg} \cdot \mathrm{ai} \cdot \mathrm{ha}^{-1}$ at $15 \mathrm{DAP}$, and penoxsulam + cyhalofop applied at 0.072 and $0.108 \mathrm{~kg} \cdot \mathrm{ai} \cdot \mathrm{ha}^{-1}$ at $15 \mathrm{DAP}$. Herbicides were sprayed using a research track sprayer that delivered $210 \mathrm{~L} \mathrm{ha}^{-1}$ spray solution through flat-fan nozzles.

In the screenhouse, the pots were laid out in a complete block design. There were eight replications for each treatment. Plant samples were harvested 30 DAP. Seedling survival percent, plant height, and aboveground shoot biomass were measured for both rice and corn. For biomass, plant samples were placed in an oven at $70^{\circ} \mathrm{C}$ for 72 hours.

\subsection{Field Experiment}

A field experiment was conducted in a randomized complete block design and there were three replications of each treatment. This experiment was conducted two times (and therefore, a total of six replications). The experimental site was rotovated twice using a 4-wheel tractor before crop planting and then it was leveled using a wooden board.

Before crop planting, corn (cv. P3482YR) seeds were broadcast uniformly at a rate of 50 seeds $\mathrm{m}^{-2}$. These corn seeds were collected from the crop (glyphosate-resistant) grown on the farm. Rice (cv. Rc222) was planted by hand at $100 \mathrm{~kg} \cdot \mathrm{ha}^{-1}$ in $20 \mathrm{~cm}$ wide rows. The crop was planted on January 23, 2013 (for first experiment) and March 20, 2013 (for second experiment). Immediately after planting, a light irrigation was given and then irri- gated as required by the crop. Nitrogen $(\mathrm{N})$ was applied in two equivalent splits $\left(30 \mathrm{~kg} \cdot \mathrm{N} \cdot \mathrm{ha}^{-1}\right)$ at 14 and $28 \mathrm{DAP}$.

There were eight weed control treatments: weed-free (no corn was broadcast in this treatment); weedy (nontreated control); butachlor + propanil at $0.60 \mathrm{~kg} \cdot \mathrm{ai} \mathrm{ha}^{-1}$ at 6 DAP; oxadiazon at $0.75 \mathrm{~kg} \cdot \mathrm{ai} \cdot \mathrm{ha}^{-1}$ at $1 \mathrm{DAP}$; bispyribac at 0.030 and $0.045 \mathrm{~kg} \cdot \mathrm{ai} \cdot \mathrm{ha}^{-1}$ at $14 \mathrm{DAP}$, oxadiazon at $0.75 \mathrm{~kg} \cdot \mathrm{ai} \cdot \mathrm{ha}^{-1}$ at 1 DAP followed by bispyribac at $0.030 \mathrm{~kg} \cdot \mathrm{ai} \cdot \mathrm{ha}^{-1}$ at $14 \mathrm{DAP}$; and oxadiazon at 0.75 $\mathrm{kg} \cdot \mathrm{ai} \cdot \mathrm{ha}^{-1}$ at 1 DAP followed by bispyribac at $0.045 \mathrm{~kg}$ ai ha ${ }^{-1}$ at 14 DAP. Herbicides were applied with a knapsack sprayer that delivered $320 \mathrm{~L} \cdot \mathrm{ha}^{-1}$ of spray solution through flat-fan nozzles.

At 35 DAP, rice and corn plants were sampled from a central $1-\mathrm{m}^{2}$ area. For rice, leaf area and aboveground biomass were measured. For corn, plant density and biomass were measured. Biomass was measured after oven drying samples at $70^{\circ} \mathrm{C}$ for 72 hours.

\subsection{Statistical Analyses}

Data from screenhouse and field experiments were analyzed with analysis of variance (ANOVA) to evaluate differences between treatments and the means were separated by least significant difference (LSD) at the 5\% level of significance [6].

\section{Results and Discussion}

\subsection{Screenhouse Experiment}

In the pot study, herbicide application did not influence seedling survival of rice (Table 1). These results suggest that the tested herbicides can be used on rice. In fact, these herbicides are being used in dry-seeded rice to manage broad-spectrum of weed flora [7,8]. Tallest rice plants were observed in the nontreated control (Table 1). In the nontreated control, rice plants grew with corn plants and the stiff competition might have resulted in tallest rice plants in this treatment. All herbicides suppressed the height of rice plants. Bispyribac is known to cause stunting in rice [9]. However, its tolerance is dependent on rice cultivar $[10,11]$.

Bispyribac application at both rates provided complete control of corn (Table 1). The next best treatment was fenoxaprop + ethoxysulfuron at both doses $(19 \%-25 \%$ survival). After the application of penoxsulam + cyhalofop, $50 \%-70 \%$ corn seedlings survived. Similar response was observed for corn height. In the nontreated control, corn produced highest biomass $\left(2.7 \mathrm{~g} \cdot\right.$ plant $\left.^{-1}\right)$. Bispyribac application killed all corn plants and therefore no biomass was observed. Although corn produced higher biomass in the penoxsulam + cyhalofop treatment $\left(0.64-0.67 \mathrm{~g} \cdot\right.$ plant $\left.^{-1}\right)$ compared to fenoxaprop + ethoxysulfuron treatment $\left(0.36-0.39 \mathrm{~g} \cdot\right.$ plant $\left.^{-1}\right)$, the difference 
Table 1. Effect of herbicides on the survival, height, and biomass of rice and corn seedlings.

\begin{tabular}{|c|c|c|c|c|c|c|}
\hline \multirow{2}{*}{ Treatments } & \multicolumn{3}{|c|}{ Rice } & \multicolumn{3}{|c|}{ Corn } \\
\hline & Survival & Height & Biomass & Survival & Height & Biomass \\
\hline & $(\%)$ & $\left(\mathrm{cm} \cdot\right.$ plant $\left.^{-1}\right)$ & $\left(\mathrm{g} \cdot\right.$ plant $\left.^{-1}\right)$ & $(\%)$ & $\left(\mathrm{cm} \cdot\right.$ plant $\left.^{-1}\right)$ & $\left(\mathrm{g} \cdot\right.$ plant $\left.^{-1}\right)$ \\
\hline Control & 100 & 38.2 & 0.149 & 100 & 81.6 & 2.71 \\
\hline Bispyribac 0.030 & 100 & 27.1 & 0.114 & 0 & 0 & 0 \\
\hline Bispyribac 0.045 & 94 & 30.4 & 0.165 & 0 & 0 & 0 \\
\hline Fenoxaprop + ethoxysulfuron 0.045 & 98 & 33.6 & 0.210 & 25 & 24.5 & 0.36 \\
\hline Fenoxaprop + ethoxysulfuron 0.068 & 100 & 25.5 & 0.099 & 19 & 21.4 & 0.39 \\
\hline Penoxsulam + cyhalofop 0.072 & 100 & 28.2 & 0.069 & 71 & 39.7 & 0.67 \\
\hline Penoxsulam + cyhalofop 0.108 & 88 & 28.4 & 0.075 & 54 & 40.6 & 0.64 \\
\hline $\mathrm{LSD}_{0.05}$ & NS & 4.8 & 0.070 & 16 & 13.2 & 0.54 \\
\hline
\end{tabular}

Abbreviations: $\mathrm{LSD}_{0.05}$, least significant difference at $5 \%$ level of significance; NS, nonsignificant.

was statistically nonsignificant. Because of strong competition with corn, rice produced the lowest amount of biomass in the penoxsulam + cyhalofop treatment (Table 1). Although bispyribac completely controlled volunteer corn seedlings, rice did not produce highest biomass in this treatment. This response could be due to the phytotoxic effect of bispyribac on rice. In earlier studies in the Philippines and USA, bispyribac was reported to cause toxic effect on rice [9-11]. In the Philippines, for example, bispyribac reduced rice shoot biomass by up to $37 \%$ [9]. In another study, bispyribac at $0.03 \mathrm{~kg} \cdot \mathrm{ha}^{-1}$ reduced rice biomass by $65 \%$ compared with a nontreated control [12]. Rice susceptibility to fenoxaprop has also been reported [13].

\subsection{Field Experiment}

In the screenhouse experiment, fenoxaprop + ethoxysulfuron and penoxsulam + cyhalofop did not provide effective control of corn seedlings and therefore, these treatments were not included in the field experiment. Plots treated with a single application of pre-emergence herbicide (i.e., oxadiazon) or treated with no herbicide had greater density and biomass of corn seedlings compared with other treatments (Figure 1). The application of early post-emergence (butachlor + propanil) or late post-emergence (bispyribac) herbicides reduced corn density compared with the nontreated control (weedy) (Figure 1(a)). Compared with the weedy plots, butachlor + propanil and bispyribac-treated plots produced fewer biomass of corn seedlings (Figure 1(b)). Compared with the weedy plots, sole application of bispyribac suppressed corn biomass by $60 \%-82 \%$ and sequential application of oxadiazon and bispyribac suppressed corn biomass by $89 \%-91 \%$. Although the plots treated with the sequential application of oxadiazon and bispyribac $\left(9-11 \mathrm{~g} \cdot \mathrm{m}^{-2}\right)$ had lower

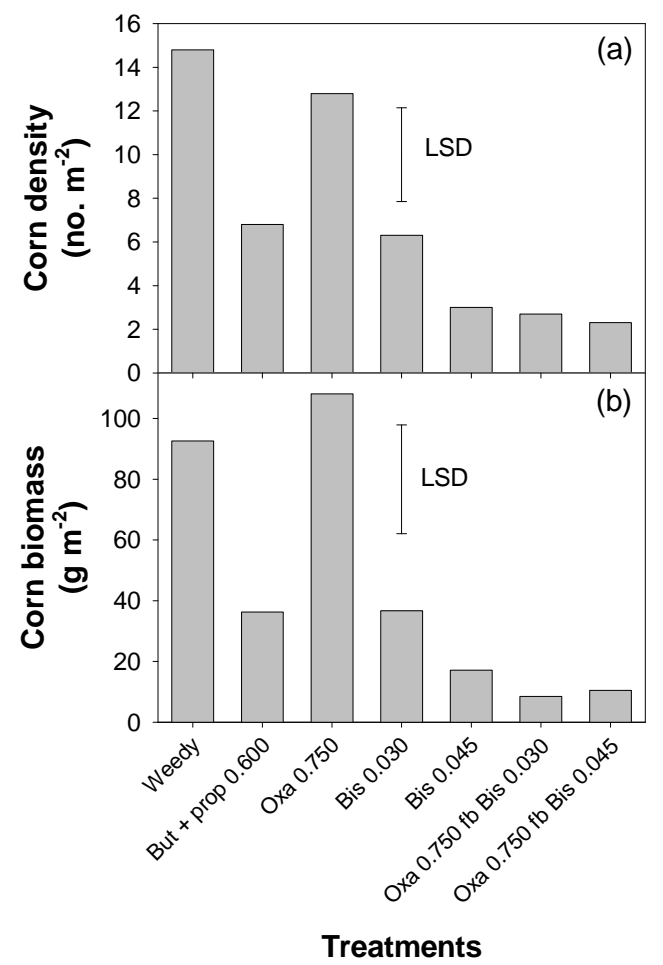

Figure 1. Effect of weed control treatments [weedy (nontreated control); butachlor + propanil at $0.600 \mathrm{~kg} \cdot \mathbf{a i} \cdot \mathrm{ha}^{-1}$; oxadiazon at $0.75 \mathrm{~kg} \cdot \mathrm{ai}^{\cdot} \mathrm{ha}^{-1}$; bispyribac at 0.030 and 0.045 $\mathrm{kg}$ ai ha ${ }^{-1}$; oxadiazon at $0.75 \mathrm{~kg}^{\mathrm{ai}} \mathrm{ha}^{-1}$ followed by bispyribac at $0.030 \mathrm{~kg} \cdot \mathrm{ai} \cdot \mathrm{ha}^{-1}$; and oxadiazon at $0.75 \mathrm{~kg} \cdot \mathrm{ai}^{\circ} \cdot \mathrm{ha}^{-1}$ followed by bispyribac at $0.045 \mathrm{~kg} \cdot \mathrm{ai}^{\circ} \mathrm{ha}^{-1}$ l on density (a) and biomass (b) of corn.

corn biomass than the plots treated with bispyribac alone $\left(17-37 \mathrm{~g} \cdot \mathrm{m}^{-2}\right)$, the difference was statistically nonsignificant.

Rice produced highest leaf area $\left(4600 \mathrm{~cm}^{2} \cdot \mathrm{m}^{-2}\right)$ and biomass $\left(38 \mathrm{~g} \cdot \mathrm{m}^{-2}\right)$ in the weed-free plots (Figure 2). 


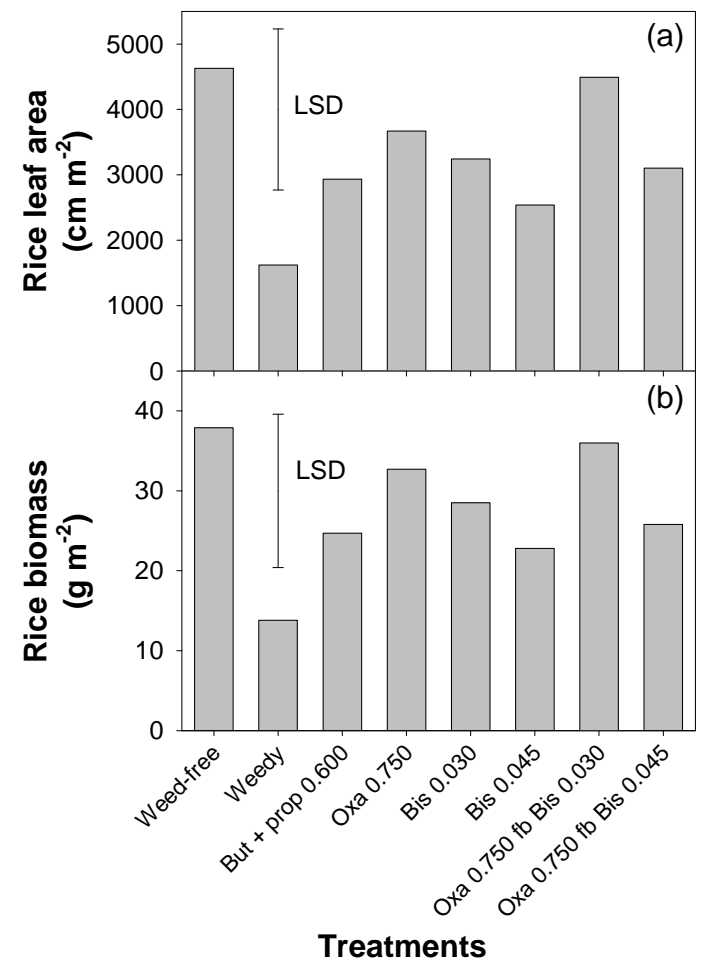

Figure 2. Effect of weed control treatments [weed-free ( no corn was broadcast in this treatment; weedy (nontreated control); butachlor + propanil at $0.600 \mathrm{~kg} \cdot \mathrm{ai}^{\circ} \cdot \mathrm{ha}^{-1}$; oxadiazon at $0.75 \mathrm{~kg} \cdot$ ai $^{\circ} \mathrm{ha}^{-1}$; bispyribac at 0.030 and $0.045 \mathrm{~kg} \cdot \mathrm{ai} \cdot \mathrm{ha}^{-1}$; oxadiazon at $0.75 \mathrm{~kg} \cdot \mathrm{ai}^{\circ} \cdot \mathrm{ha}^{-1}$ followed by bispyribac at 0.030 $\mathrm{kg} \cdot \mathrm{ai} \cdot \mathrm{ha}^{-1}$; and oxadiazon at $0.75 \mathrm{~kg} \cdot \mathrm{ai}^{\cdot} \mathrm{ha}^{-1}$ followed by bispyribac at $0.045 \cdot \mathrm{kg} \cdot \mathrm{ai}^{\cdot} \cdot \mathrm{ha}^{-1}$ ] on leaf area (a) and biomass (b) of rice.

The next best treatment was oxadiazon followed by bispyribac at $0.03 \mathrm{~kg} \cdot \mathrm{ha}^{-1}$, which produced a leaf area of $4500 \mathrm{~cm}^{2} \cdot \mathrm{m}^{-2}$ and biomass of $36 \cdot \mathrm{g} \cdot \mathrm{m}^{-2}$. Compared with the nontreated plots (weedy), the plots treated with oxadiazon followed by bispyribac at $0.03 \mathrm{~kg} \cdot \mathrm{ha}^{-1}$ produced 2.8 times more leaf area and 2.6 times more rice biomass.

The results of our study suggest that volunteer corn seedlings can be managed by using bispyribac in dryseeded rice systems. However, bispyribac may cause phytotoxic effect on some rice cultivars. In previous studies, rice toxicity due to bispyribac application has been reported [10]. However, there was little effect on grain yield of rice. Furthermore, bispyribac is widely used to manage weeds in direct-seeded rice systems in other countries, e.g., India and Sri Lanka $[8,14,15]$. Therefore, in the absence of other effective management strategies, bispyribac can be used to manage volunteer corn seedlings. In dry-seeded rice systems, weeds are the most important biological constraints as weeds emerge simultaneously with rice seedlings [4]. Therefore, there is a need to apply pre-emergence herbicides to achieve effective weed control. At present, a pre-emergence followed by one or two post-emergence herbicides are applied in dry-seeded rice systems $[7,16]$. Our study also found that oxadiazon as pre-emergence and bispyribac as post-emergence can control volunteer corn seedlings. However, there is a need to integrate other control measures, such as the use of stale seedbed practice, to achieve complete control of corn seedlings in dry-seeded rice systems.

\section{Conclusion}

Volunteer corn seedlings severely compete with rice crop in dry-seeded rice systems, in which there is no standing water. Bispyribac-sodium can be used to control such corn seedlings in rice. The sequential application of oxadiazon and bispyribac suppressed corn biomass by $90 \%$ as compared with the non-treated control.

\section{REFERENCES}

[1] M. C. R. Alberto, R. J. Buresh, T. Hirano, A. Miyata, R. Wassmann, J. R. Quilty, T. Q. Correa Jr. and J. Sandro, "Carbon Uptake and Water Productivity for Dry-Seeded Rice and Hybrid Maize Grown with Overhead Sprinkler Irrigation," Field Crops Research, Vol. 146, 2013, pp. 51-65. http://dx.doi.org/10.1016/i.fcr.2013.03.006

[2] J. Timsina, R. J. Buresh, A. Dobermann and J. Dixon, "Rice-Maize Systems in Asia: Current Situation and Potential," International Rice Research Institute, Los Banos, 2011, 235 p.

[3] B. S. Chauhan and J. Opeña, "Effect of Plant Geometry on Growth and Yield of Corn in the Rice-Corn Cropping System," American Journal of Plant Sciences, Vol. 4, No. 10, 2013, pp. 1928-1931.

http://dx.doi.org/10.4236/ajps.2013.410237

[4] B. S. Chauhan, "Weed Ecology and Weed Management Strategies for Dry-Seeded Rice in Asia," Weed Technology, Vol. 26, No. 1, 2012, pp. 1-13.

http://dx.doi.org/10.1614/WT-D-11-00105.1

[5] B. S. Chauhan, G. Mahajan, V. Sardana, J. Timsina and M. L. Jat, "Productivity and Sustainability of the RiceWheat Cropping System in the Indo-Gangetic Plains of the Indian Subcontinent: Problems, Opportunities, and Strategies," Advances in Agronomy, Vol. 117, 2012, pp. 315-369.

http://dx.doi.org/10.1016/B978-0-12-394278-4.00006-4

[6] GenStat 8. 0, "GenStat Release 8 Reference Manual," VSN International, Oxford, 2005, 343 p.

[7] B. S. Chauhan and J. Opeña, "Effect of Tillage Systems and Herbicides on Weed Emergence, Weed Growth, and Grain Yield in Dry-Seeded Rice Systems," Field Crops Research, Vol. 137, 2012, pp. 56-69. http://dx.doi.org/10.1016/j.fcr.2012.08.016

[8] R. Gopal, R. K. Jat, R. K. Malik, V. Kumar, M. M. Alam, M. L. Jat, M. A. Mazid, Y. S. Saharawat, A. McDonald and R. Gupta, "Direct Dry Seeded Rice Production Technology and Weed Management in Rice Based Systems," Technical Bulletin, International Maize and Wheat Improvement Center, New Delhi, 2010, 28 p.

[9] B. S. Chauhan and D. E. Johnson, "Growth Response of 
Direct-Seeded Rice to Oxadiazon and Bispyribac-Sodium in Aerobic and Saturated Soils," Weed Science, Vol. 59, No. 1, 2011, pp. 119-122. http://dx.doi.org/10.1614/WS-D-10-00075.1

[10] W. Zhang and E. P. Webster, "Shoot and root Growth of Rice (Oryza sativa L.) in Response to V-10029," Weed Technology, Vol. 16, No. 4, 2002, pp. 768-772. http://dx.doi.org/10.1614/0890-037X(2002)016[0768:SA RGOR]2.0.CO;2

[11] W. Zhang, E. P. Webster and C. T. Leon, "Response of Rice Cultivars to V-10029," Weed Technology, Vol. 19, No. 2, 2005, pp. 307-311. http://dx.doi.org/10.1614/WT-03-278

[12] J. A. Bond, T. W. Walker, E. P. Webster, N. W. Buehring and D. L. Harrell, "Rice Cultivar Response to Penoxsulam," Weed Technology, Vol. 21, No. 4, 2007, pp. 961965. http://dx.doi.org/10.1614/WT-07-003.1

[13] D. M. Oosterhuis, S. D. Wullschleger, R. E. Hampton and R. A. Ball, "Physiological Response of Rice (Oryza sa- tiva) to Fenoxaprop," Weed Science, Vol. 38, No. 6, 1990, pp. 459-462.

[14] B. S. Chauhan, A. S. K. Abeysekara, S. D. Kulatunga and I. U. Madusanka, "Weed Growth and Grain Yield, as Affected by Herbicides, in Dry-Seeded Rice in Sri Lanka," Journal of Crop Improvement, Vol. 27, No. 4, 2013, pp. 419-429. http://dx.doi.org/10.1080/15427528.2013.789810

[15] B. S. Chauhan, A. S. K. Abeysekara, S. D. Kulatunga, I. U. Madusanka and S. B. Abugho, "Emergence and Growth of Weeds in Broadcast-Rice Systems in Sri Lanka," Canadian Journal of Plant Protection, Vol. 1, No. 3, 2013, pp. 83-90.

[16] B. S. Chauhan and J. Opeña, "Implications of Plant Geometry and Weed Control Options in Designing a LowSeeding Seed-Drill for Dry-Seeded Rice Systems," Field Crops Research, Vol. 144, 2013, pp. 225-231. http://dx.doi.org/10.1016/j.fcr.2012.12.014 